\title{
DINAMIKA MASYARAKAT LOKAL DI PERBATASAN
}

\author{
Zaenuddin Hudi Prasojo \\ STAIN Pontianak \\ e-mail: zaestain@yahoo.com
}

\begin{abstract}
Community members living in borderland areas in Indonesia tended to be clasified as under-developed society in development aspects. Study on the borderland areas is still limited both in quantity and the impact of the study. Nanga Badau located in borderland between West Kalimantan (Indonesia) and Serawak (Malaysia) is one of the under-developed borderland area. This paper revealed the dynamic issues and the existence of local tradition in the context of globalization. It was showed that the original attitude of warn, friendly, and respect visitors express their openess toward global trend but still keep on local style. They are also realized on their position among global community. The open access abroad effected in the development of the interaction, information, and communication patterns among Iban Dayak. Sophisticated devices like mobile phone and television are familiar among Iban dayak in borderland area.
\end{abstract}

$* * *$

Masyarakat perbatasan yang ada di Indonesia cenderung masuk dalam kelompok masyarakat yang tertinggal dari berbagai aspek pembangunan. Kajian mengenai masyarakat lokal di wilayah-wilayah perbatasan di Indonesia belum terlalu menggembirakan baik dari segi jumlah maupun dari segi dampak hasil kajian yang berupa aksi kebijakan pasca kajian. Nanga Badau yang terletak di daerah perbatasan Kalimantan Barat (Indonesia) dan Serawak (Malaysia) merupakan salah satu wilayah perbatasan yang tertinggal. Tulisan ini memoret isu-isu dinamika dan eksistensi tradisi lokal dalam kerangka globalisasi. Tampak bahwa sikap ramah dan menghormati pendatang merupakan salah satu bentuk nyata bahwa mereka sangat terbuka dengan adanya arus global dan lokal. Mereka juga memiliki kesadaran diri akan posisi mereka sebagai bagian dari penduduk dunia. Adanya ruang interaksi bagi dunia luar, seperti mudahnya akses keluar masuk ke negara lain mengakibatkan pola interaksi, informasi dan komunikasi etnis Iban menjadi berkembang. Hal tersebut dapat dilihat pada aktivitas masyarakat Iban sehari-hari yang telah memanfaatkan dan menggunakan perangkat handphone, televisi dan teknologi modern lainnya.

Keywords: perbatasan, Nanga Badau, tradisi lokal, tertinggal, globalisasi 


\section{A. Pendahuluan}

Isu-isu tentang dinamika masyarakat lokal perbatasan di Indonesia adalah tema yang selayaknya mendapat perhatian lebih serius dari berbagai pihak di Indonesia, baik oleh masyarakat di wilayah perbatasan itu sendiri, pemerintah daerah perbatasan dan pemerintah pusat di Jakarta serta masyarakat Indonesia secara umum sebagai bagian dari masyarakat internasional. Setidaknya ada beberapa argumen yang mendukung pernyataan mengenai pentingnya kajian masyarakat lokal di perbatasan. Pertama, daerah perbatasan adalah wilayah strategis yang menjadi wajah sebuah negara, dalam hal ini Negara Kesatuan Republik Indonesia (NKRI), karena wilayah-wilayah tersebut menjadi pintu masuk bagi warga asing atau pihak luar lainnya yang berkepentingan untuk masuk ke wilayah NKRI. Kedua, masyarakat perbatasan yang ada di NKRI cenderung masuk dalam kategori masyarakat yang tertinggal dari berbagai aspek pembangunan. Ketiga, kajian mengenai masyarakat lokal di wilayah-wilayah perbatasan di Indonesia belum terlalu menggembirakan baik dari segi jumlah maupun dari segi dampak hasil kajian yang berupa aksi kebijakan pasca kajian. ${ }^{1}$

Ketiga argumen tersebut mendorong penulis untuk melakukan penelitian yang bertujuan memotret berbagai isu yang sedang menjadi perbincangan hangat dan penting di salah satu wilayah perbatasan di Indonesia, yaitu di Nanga Badau yang terletak di daerah perbatasan Kalimantan Barat (Indonesia) dan Serawak (Malaysia). Penelitian ini memoret isu-isu yang berkembang di kalangan masyarakat bawah (grassroots), kalangan tokoh/ pemuka, birokrasi pemerintah dan unsur pimpinan (elite) dalam masyarakat. Diantara isu-isu penting yang berkembang dan menarik adalah tentang globalisasi dan dampaknya di daerah perbatasan, pengaruh modernitas dan eksistensi masyarakat di perbatasan, kebijakan pemerintah di tengah gejolak kesetaraan kehidupan yang layak terhadap seluruh warga negara Indonesia termasuk di wilayah perbatasan dan daerah terpencil dan isu tentang reformasi birokrasi dalam kaitannya dengan nasionalisme yang seolah mengikis simbol Bhinneka Tunggal Ika. Nampak juga di lapangan bahwa

\footnotetext{
1 Marsetio, "Konstruksi Marginalitas Masyarakat Perbatasan, Studi Kasus Kepulauan Natuna", Disertasi, tidak diterbitkan, (Yogyakarta: Universitas Gadjah Mada, 2012).
} 
modernitas, walaupun secara tidak langsung, memberikan dorongan perubahan atas menguatnya kearifan lokal atau tradisi lokal dari komunitaskomunitas terpencil dan perbatasan.

Tulisan ini membicarakan tiga dari sekian isu penting yang ditemukan dalam dinamika masyarakat Badau. Secara khusus tulisan ini memotret kehidupan masyarakat Dayak Iban yang menjadi penduduk lokal yang merupakan warga asli daerah tersebut. Pertama, isu proses pembangunan masyarakat adalah sebuah isu yang semestinya dikaji secara serius, khususnya oleh pemerintah. Kajian mengenai proses pembangunan masyarakat di Badau menjadi sebuah keharusan karena sebagai salah satu wilayah perbatasan di Kalimantan Barat, masyarakat di Badau memiliki berbagai keterbatasan yang kemudian nampak sangat menyolok jika dibandingkan dengan masyarakat yang berada di wilayah Lubok Antu, Serawak. Tulisan ini membahas isu-isu faktual pembangunan yang menjadi bagian kehidupan sehari-hari masyarakat Badau yang telah berjalan sekian lama dengan catatan-catatan perkembangan yang sangat lamban. Selanjutnya, kelambanan perkembangan Badau tersebut membawa pada isu analisis kebijakan pembangunan yang mesti dilakukan dengan tepat sehingga proses pembangunan dapat mencapai tujuan-tujuan yang diharapkan. Kesimpulan tentang kelambanan perkembangan Badau tersebut juga dapat dipahami sebagai sebuah kritik atas belum maksimalnya berbagai usaha dan proses pembangunan yang telah dan sedang berjalan sehingga perlu mendapat perhatian yang lebih serius dari berbagai pihak.

Kedua, isu-isu utama yang berkembang di Nanga Badau antara lain meliputi isu hubungan negara dan masyarakat perbatasan dalam berbagai aspek, ternasuk kegalauan identitas dan nasionalisme bangsa Indonesia di wilayah perbatasan. Isu-isu tersebut merupakan isu-isu sentral dalam kerangka pengembangan wilayah-wilayah pinggiran Negara Kesatuan Republik Indonesia (NKRI) karena isu-isu tersebut adalah yang sebenarnya menjadi ruh dari pembangunan. Isu-isu tentang fungsi negara adalah isu sentral yang menjadi infrastruktur utama di mana peran negara dalam seluruh aspek kebangsaan dan kenegaraan adalah tiang utama dalam roda organisasi NKRI di seluruh wilayahnya, termasuk di Badau sebagai bagian yang tidak terpisahkan dari NKRI. 
Ketiga, isu penting lainnya adalah mengenai hasil-hasil dari pembangunan dan usaha-usaha yang telah dilakukan oleh negara dan masyarakat yang terwujud dalam kehidupan sehari-hari melalui praktek-praktek individu dan kelompok yang merupakan manifestasi dari nilai-nilai identitas bangsa. Sangat penting untuk digarisbawahi di sini adalah bahwa terdapat fakta kesenjangan tingkat ekonomi masyarakat di wilayah perbatasan (Badau) yang berdampak pada identitas kebangsaan (nasionalisme) dan mayarakat wilayah perbataan di negara tentangga (wilayah Lubok Antu, Serawak Malaysia).

Pemerintah (pusat dan daerah) sebagai salah satu pihak yang bertanggungjawab dalam bidang kebijakan untuk pembangunan, sebenarnya telah melakukan berbagai upaya untuk memajukan Badau sebagai bagian dari wilayah NKRI. Pemerintah daerah dan pemerintah pusat telah mendorong perkembangan wilayah perbatasan menuju ke arah yang lebih baik dengan melakukan berbagai upaya melalui program-program dan kucuran dana dari berbagai instansi pemerintahan. Target-target pembangunan dari pemerintah diarahkan untuk menunjang keberlangsungan hidup yang lebih baik dan berkehidupan yang layak bagi setiap Warga Negara Indonesia. Bahkan pemerintah telah membuka kesempatan kepada investor untuk ikut berpartisipasi dalam pembangunan di daerah pedalaman, terpencil dan perbatasan seperti di Kabupaten Kapuas Hulu yang mencakup Badau dan sekitarnya.

Walaupun masih belum maksimal, sejak dibukanya kesempatan bagi investor dan perusahaan, baik itu swasta maupun negeri, daerah ini juga telah dianggap dapat meningkatkan kehidupan ekonomi yang ternyata juga mendapatkan respon sangat baik dari masyarakat kawasan perbatasan. Selanjutnya, tentu saja peluang untuk mendapatkan pekerjaan menjadi lebih terbuka. Masyarakat yang dahulunya bekerja sebagai petani dan berladang dengan memanfaatkan pekarangan dan kekayaan sumber daya alam kini memiliki peluang untuk merubah tradisi produktivitas komoditas produksi hasil bumi untuk mendapatkan peluang yang lebih besar.

Selain itu, sebagian masyarakat juga mendapatkan kesempatan untuk menjadi tenaga kerja di perkebunan yang pada gilirannya meningkatkan pendapatan mereka. Jika dilihat kembali sejarah pembangunan di era Orde 
Baru, di bawah payung perkembangan nasional sebenarnya pemerintah saat itu telah mulai menggerakkan berbagai elemen masyarakat sampai ke pelosok desa, demi untuk menyukseskan apa yang kemudian dikenal sebagai proyek pembangunan nasional. Namun sangat disayangkan bahwa pembangunan tersebut tidak berjalan mulus sehingga Badau dan banyak lagi wilayah perbatasan di Indonesia seperti Nunukan dan Jagoi Babang saat ini masih menjadi wilayah yang tertinggal dari berbagai aspek pembangunan.

\section{B. Badau: Satu dari Lima Titik Perbatasan di Kalimantan Barat}

Sebagai salah satu dari 5 (lima) wilayah perbatasan (border area) di wilayah Kalimantan Barat yang berbatasan dengan wilayah Serawak, Malaysia, yang dilengkapi dengan Pos Lintas Batas (PLB), Badau menjadi daerah yang memiliki kompleksitas persoalan yang berkarakteristik perbatasan. Fakta bahwa semua wilayah perbatasan di wilayah Kalimantan Barat yang berbatasan dengan Negara lain tersebut adalah termasuk dalam kelompok daerah tertinggal (komunitas terpencil) di NKRI juga menjadi faktor tersendiri yang mempengaruhi kekompleksitasan persoalan pembangunan di Badau. Selain itu, kondisi geografis Badau dalam konteks Pulau Kalimantan juga menjadikan daerah tersebut sebagai sebuah daerah perbatasan yang dapat dikelompokkan dalam kategori daerah perbatasan khusus yang perlu mendapatkan perhatian khusus pula. Untuk itu pula perlu dilakukan studi-studi yang serius yang dapat mendukung proses perhatian khusus dalam penanganan wilayah perbatasan Badau tersebut.

Dalam konteks studi Badau sebagai daerah perbatasan, sebenarnya terdapat beberapa wilayah perbatasan lain yang dapat dijadikan sebagai bahan pembanding untuk melihat isu-isu penting di Badau, khususnya studi perbatasan di titik-titik lain di Kalimantan Barat. Reed L. Wadley² bahkan memberikan contoh perbandingan studi perbatasan Kalimantan dengan perbatasan di Afrika dan Amerika. Di wilayah Kalimantan Barat, Entikong, misalnya, adalah wilayah perbatasan yang sangat dikenal oleh masyarakat

\footnotetext{
2 Wadley melakukan studi perbatasan dengan mengulas kasus perbatasan Kalimantan dalam konteks perbincangan studi perbatasan yang ada di dunia dalam berbagai aspek seperti fungsi sosial, ekonomi dan politik. Untuk lebih jelas lihat Reed L. Wadley, "Border Studies Beyond Indonesia: A Comparative Perspective”, Antropologi Indonesia. No. 67. Vol. XXVI, 2002, h. 1-11.
} 
luas, khususnya masyarakat Kalimantan Barat yang sudah banyak mendapat perhatian oleh para peneliti maupun pemerhati masalah perbatasan.

Fariastuti ${ }^{3}$ bahkan menyebutkan bahwa Entikong adalah "the busiest point of entry and exit" dibandingkan beberapa titik yang biasanya ditemukan arus masuk dan keluar manusia dan barang di Kalimantan Barat seperti Paloh, Saparan, Sidding, Jagoi Babang, Sidding, Badau dan Merakai Panjang. Entikong yang merupakan bagian dari wilayah Kapupaten Sanggau merupakan wilayah perbatasan yang memiliki PLB tertua di wilayah Kalimantan Barat dibandingkan dengan wilayah perbatasan yang lain seperti Badau di Kabupaten Kapuas Hulu, Jagoi Babang di Kabupaten Bengkayang, Senaning di Kabupaten Sintang dan Sajingan di Kabupaten Sambas.

\section{Entikong}

Entikong sebagai "pintu resmi"4 pertama dan utama telah menghubungkan masyarakat Kalimantan Barat dengan masyarakat Serawak sejak masa Orde Lama dimana perjalanan lintas batas telah mulai berlangsung dengan volume yang terus meningkat dari tahun ke tahun. Tentu saja pada masa Orde Lama belum dibangun PLB seperti yang dapat disaksikan sekarang ini. PLB Entikong dibuka pada masa Orde Baru untuk menjadikan Entikong sebagai pintu resmi tersebut. Indikasi peningkatan frekuensi aktivitas lintas batas di Entikong ini terlihat dari semakin tingginya kesibukan petugas imigrasi dan bea cukai di Entikong (Kalimantan Barat) dan Tebedu (Serawak). Pada tahun 2002 Riwanto Tirtoudarmo ${ }^{5}$ telah mencatat bahwa kesibukan lintas batas Entikong telah mengalami peningkatan sangat tajam dibandingkan dengan tahun-tahun sebelumnya, baik dari segi arus aktivitas lintas batas manusia maupun arus aktivitas barang. Money changer jalanan pun menjamur dan terkesan sangat mengganggu kenyamanan para pelaku

\footnotetext{
${ }^{3}$ Fariastuti, "Mobility of People and Goods Across the Border of West Kalimantan-Serawak", Antropologi Indonesia, No. 67, Vol. XXVI, 2002.

${ }^{4}$ Istilah pintu resmi dipinjam dari istilah yang diperkenalkan oleh Riwanto Tirtosudarmo dalam tulisannya yang berjudul "Tentang Perbatasan dan Studi Perbatasan: Sebuah Pengantar", dalam Antropologi Indonesia. No. 67, Vol. XXVI, h. iv-vi.

5 Baca Riwanto Tirtosudarmo, "Tentang Perbatasan dan Studi Perbatasan: Sebuah Pengantar", Antropologi Indonesia, No. 67, Vol. XXVI, 2002, dan Riwanto Tirtosudarmo, "Kalimantan Barat sebagai “Daerah Perbatasan": Sebuah Tinjauan Demografi Politik," Antropologi Indonesia, No. 67, Vol. XXVI, 2002.
} 
perjalanan lintas batas karena para "pengusaha" jalanan tersebut sering menawarkan jasa mereka dengan menghadang calon pelanggan dengan berbagai rayuan. Selain itu, pedagang kaki lima juga bermunculan seiring dengan perkembangan arus lintas batas di Entikong. Pedagang kaki lima tersebut membangun lapak-lapak yang memenuhi pinggiran jalan ke arah Pontianak. Sebelumnya, bahkan para pedagang kaki lima tersebut mendirikan tenda-tenda di dalam areal lintas PLB.

Beberapa fakta lintas batas di Entikong yang masih dapat disaksikan sampai hari ini tersebut menunjukkan bahwa keberadaan Entikong sebagai pintu resmi perbatasan Indonesia-Malaysia di wilayah Kalimantan Barat telah menjadi sangat penting dari berbagai aspek kehidupan di perbatasan termasuk politik, ekonomi, sosial, budaya dan pertahanan/keamanan. Robert Siburian ${ }^{6}$ bahkan menyebutkan bahwa Entikong merupakan salah satu kota tersibuk di Kalimantan Barat yang memiliki nilai perputaran uang yang sangat tinggi yang layak disebut sebagai daerah tanpa krisis ekonomi di perbatasan. Penjelasan Siburian tersebut menunjukkan bahwa Entinkong sebagai pintu resmi lintas batas telah menjadi bagian penting dalam proses perubahan sosial di Kalimantan Barat yang mestinya menjadi perhatian serius dari berbagai pihak.

\section{Jagoi Babang, Kabupaten Bengkayang}

Jagoi Babang termasuk dalam wilayah Kabupaten Bengkayang yang merupakan pemekaran dari Kabupaten Sambas. Jagoi Babang telah menjadi titik penting dalam jalur perbatasan antara Kalimantan Barat dan Serawak karena daerah ini telah menjadi "zona bebas" dimana telah terjadi arus kegiatan lintas batas sejak nenek moyang masyarakat di wilayah ini ada. Bahkan sebenarnya masyarakat di Jagoi Babang yang terbagi ke dalam dua wilayah negara yang berbeda ini (Indonesia dan Malaysia) belum lama mengenal pembagian daerah mereka. Secara kultural masyarakat di wilayah perbatasan ini masih memiliki keterkaitan kekerabatan, budaya dan adat istiadat yang berasal dari tradisi yang sama karena mereka berasal dari sub

${ }^{6}$ Robert Siburian, "Entikong: Daerah Tanpa Krisis Ekonomi di Perbatasan Kalimantan BaratSerawak”, Antropologi Indonesia, No. 67, Vol. XXVI, 2002.

Walisongo, Volume 21, Nomor 2, November 2013 
kelompok etnis yang sama yaitu yang dikenal dengan nama Dayak Bidayuh. Dayak Bidayuh yang hidup di Serikin (Malaysia) juga memiliki hubungan kekerabatan yang erat dengan Dayak Bidayuh yang tinggal di Jagoi Babang (Kalimantan Barat).

Perhatian pemerintah terhadap wilayah perbatasan Jagoi Babang sebenarnya sudah dimulai sejak lama sebelum pemekaran wilayah ini menjadi bagian dari Kabupaten Bengkayang. Pemerintah pusat telah membangun jalan yang beraspal yang menghubungkan Pontianak dengan Jagoi Babang pada periode akhir masa Orde Baru. Sebelumnya, Jagoi Babang hanya dihubungkan oleh "jalan tikus" yang juga merupakan jalur ilegal yang menghubungkan masyarakat di sekitar Jagoi Babang dan masyarakat Serikin di Serawak, Malaysia. Semenjak keberadaan jalan aspal tersebut arus lintas batas orang dan barang semakin meningkat. Bahkan pemerintah telah membangun kantor imigrai dan bea cukai di Jagoi Babang ini. Menurut beberapa informasi di lapangan, pemerintah pusat telah memiliki kesepakatan dengan pemerintah Malaysia untuk membuka PLB di wilayah Jagoi Babang ini. Akan tetapi faktanya pihak Malaysia belum juga menyambut persiapan-persiapan yang telah dilakukan oleh pihak Indonesia sampai detik ini. Maka dapat disaksikan sampai hari ini bahwa PLB Jagoi Babang belum dapat direalisasikan. Lalu bagaimana kelanjutan arus manusia dan barang dari Pontianak yang bergerak melalui jalan aspal sampai Jagoi Babang? Barang-barang yang dibawa menggunakan truk-truk dari Pontianak ternyata dilanjutkan diangkut menggunakan sepeda motor atau sepeda melalui jalan tikus yang menghubungkan ke beberapa "kampung baru" dan "pasar baru" yaitu tempat-tempat yang menjadi ramai mendadak karena aktivitas jual-beli.

\section{Senaning (Merakai Panjang), Kabupaten Sintang}

Senaning yang terletak di kawasan Merakai Panjang merupakan daerah perbatasan yang dapat dikatakan paling terpencil dibandingkan daerah perbatasan lainnya yang ada di wilayah Kalimantan Barat. Senaning yang terletak di pinggiran wilayah Kabupaten Sintang tersebut belum banyak disentuh oleh program pembangunan. Sementara itu, jalan tikus yang menghubungkan masyarakat sekitar Senaning dengan masyarakat perbatasan di wilayah Malaysia hanya tersedia jalan tikus. Berbeda dengan kondisi 
arus barang dan manusia di Entikong dan di Jagoi Babang, kondisi kegiatan lintas batas di Senaning tergolong belum mengalami perkembangan yang signifikan dari tahun ke tahun. Arus kegiatan lintas batas masih terbatas pada arus tradisional yang melibatkan masyarakat lokal setempat yang saling berinteraksi dengan masyarakat di wilayah seberang di negeri jiran.

Sentuhan pembangunan yang masih sangat jauh dari harapan di daerah Senaning juga dapat dilihat dari masih terbatanya infrastruktur yang tersedia. Jalan yang menghubungkan antara Sintang sebagai ibukota kabupaten dan Senaning sebagai gerbang perbatasan dengan Serawak juga masih sangat sederhana. Listrik sebagai salah satu kebutuhan utama pembangunan masyarakat perbatasan yang bermartabat juga masih belum memadai. Sarana transportasi juga masih belum cukup tersedia sehingga intensitas komunikasi yang terjalin antara masyarakat lokal di sekitar Senaning dengan masyarakat luar seperti di Kota Sintang dan kota-kota lainnya masih sangat rendah. Arus lalu lintas barang di perbatasan daerah ini juga belum terlalu tinggi sehingga Senaning dapat dikategorikan sebagai titik yang masih memiliki perhatian sangat rendah baik oleh masyarakat maupun pemerintah pusat dan daerah.

\section{Sajingan, Kabupaten Sambas}

Berbeda dengan kondisi yang terjadi di Entikong di satu sisi dan Senaning di sisi lainnya, Sajingan lebih mendekati pada kondisi yang ada di Jagoi Babang dari segi arus lintas batas manusia dan barang. Masyarakat yang ada di sekitar Sajingan adalah masyarakat Melayu yang telah memiliki jalur tradisional lintas batas ke negeri jiran di Serawak sejak lama. Bahkan hubungan kultural antara mayarakat Melayu di Sambas secara umum dan masyarakat Melayu di Kuching sebagai ibukota Serawak telah terjadi sejak masa pra kolonial. Hubungan kerabatan yang dekat antara masyarakat di kedua wilayah tersebut dapat ditelusuri melalui silsilah kekerabatan keluarga Keraton Sambas yang merupakan family dari keluarga Kerajaan Brunei yang dalam perjalanannya menggunakan jalur pantai melalui Kuching. Daerah Sajingan kemudian menjadi jalur alternatif darat yang menghubungkan mayarakat Melayu di Sambas dan masyarakat Melayu di Kuching melalui Sungai Aruk. Jalur darat Sajingan ini memberikan kemudahan yang sangat 
berarti bagi masyarakat Sambas karena sebelumnya mereka harus menempuh perjalanan yang jauh dan memutar melalui Entikong untuk sampai ke Kuching, Serawak.

Sementara Entikong telah lama menjadi pintu resmi lintas batas antara Indonesia dan Malaysia, Sajingan baru saja memiliki pintu resmi lintas batas yaitu ketika PLB dibuka untuk jalur resmi di tahun 2012. Sajingan dengan demikian bernasib lebih baik dari Jagoi Babang yang sampai saat ini belum menjadi pintu resmi. Perhatian pembangunan di Sajingan masih tergolong rendah dengan bukti-bukti fisik yang dapat disaksikan saat ini. Namun demikian, pembangunan di Sajingan telah jauh lebih baik dibandingkan dengan pembangunan di Jagoi Babang dan Senaning. Jalan yang menghubungkan antara Kota Sambas sebagai ibukota Kabupaten Sambas dan Sajingan telah tersedia walaupun dengan kondisi yang masih sederhana. Sarana listrik pun udah tersedia sehingga pengembangan sektor lain seperti perdagangan dapat berjalan. Bahkan, walaupun Sajingan menjadi daerah perbatasan yang saat ini memiliki kondisi yang hampir sama dengan Badau dari sisi pembangunan sarana fisik, namun ia memiliki persoalan nasionalisme yang lebih serius dibandingkan Badau. Insiden Camar Bulan yang mencuat beberapa waktu lalu memberikan indikasi ancaman perbatasan yang serius di wilayah perbatasan Kabupaten Sambas ini.7

\section{Nanga Badau di Kapuas Hulu}

Secara geografis Kecamatan Nanga Badau di bagian Utara berbatasan langsung dengan Distrik Lubok Antu, Sriaman Negara Serawak, Malaysia. Wilayah utara tersebut merupakan kawasan perbukitan dan hamparan lembah yang berbukit dan bergelombang yang kaya akan sumber daya alam. Secara administratif Kecamatan Badau masuk dalam wilayah Kabupaten Kapuas Hulu atau yang biasa dikenal oleh masyarakat Kalimantan Barat sebagai Bumi Uncak Kapuas. Sebagai sebuah kecamatan sekaligus beranda negara, Kecamatan Badau yang beribu kota Nanga Badau tersebut memiliki

7 Insiden Camar Bulan muncul ketika terjadi isu pencaplokan wilayah NKRI oleh Malaysia pada tahun 2012 lalu. Camar Bulan adalah salah satu desa perbatasan yang terletak di Kabupaten Sambas. 
luas wilayah kurang lebih $700 \mathrm{~km}^{2}$ dan beriklim tropis seperti halnya daerah lain di Kalimantan Barat. Kecamatan Badau mempunyai curah hujan yang cukup tinggi. Badau juga memiliki potensi alam yang sangat besar sehingga sering dikatakan sebagai surganya SDA alami di pedalaman Kalimantan; tanah surga bagi habibatnya seperti flora dan fauna (hewan, tumbuhan persawahan, perkebunan baik itu tanaman karet, buah-buahan, sayur mayur dan hasil bumi lainnya). Di bidang perikanan, Kecamatan Badau menyumbangkan bermacam-macam hasil ikan seperti, jelawat, semah, toman, tengadak dan lain sebagainya. Dari sisi pariwisata wilayah Badau memiliki posisi strategis untuk menjagkau kawasan Taman Nasional Danau Sentarum (TNDS), salah satu hutan hujan basah terbesar di Kalimantan Barat dengan potensi wisata yang sangat besar. Tidak hanya itu, produksi andalan kawasan Danau Sentarum juga sangat menjanjikan yang meliputi madu, ayam kampong, buah-buahan, kopi dan lada.

Suku terbesar yang menghuni kawasan Badau adalah Dayak Iban dan Melayu. Berdasarkan statistik, dari jumlah penduduk 6.369 di kecamatan tersebut, suku Iban menduduki kurang lebih 60\%, sementara suku Melayu presentasinya sebanyak 31\%. Selebihnya $9 \%$ di duduki suku-suku lain seperti, Kantuk, Jawa, dan Minang. Besarnya jumlah mayoritas Iban di kawasan tersebut persebarannya menempati 16 desa dari 19 desa yang ada di kecamatan Nanga Badau. Sedangkan orang melayu tersebar di empat desa yakni, Badau 1, Badau 2, Raden Sura dan Pulau Majang. Mayoritas masyarakat Dayak Iban berafiliasi dengan agama lokal dan agama Katolik, dan sebagian kecil memeluk Islam. Masyarakat suku Melayu di Badau, seperti halnya masyarakat Melayu di tempat lain di Kalimantan Barat, memeluk agama Islam. Suku Kantuk dan suku Dayak lainnya juga masih banyak yang masih berafiliasi dengan agama nenek moyang disamping juga dengan agama Kristen dan Islam.

Jarak Badau dengan Putussibau sebagai ibu kota Kabupaten Kapuas Hulu mencapai $120 \mathrm{~km}$, dengan Pontianak sebagai ibu kota provinsi Kalimantan Barat mencapai lebih kurang 1000 km. Sementara itu jarak antara Badau dan Lubok Antu Serawak Malaysia hanya berkisar antara 10 km saja. Data penduduk Badau berjumlah 6.369 jiwa, terdiri dari 3.394 lakilaki dan 2.975 perempuan dengan kurang lebih 1.966 kepala keluarga. Mata 
pencarian terbesar yakni petani dan pekebun sebesar 1435. Hal ini dikarenakan pendudukanya mayoritas tinggal di daerah pedesaan yang bermata pencaharian pokoknya bertani dan berkebun. Sebagai kawasan perbatasan, jarak tempuh ke ibu kota Kabupaten terhitung sangat jauh, harus menempuh perjalanan kurang lebih 5 jam dengan menggunakan kendaraan bermotor. Tentu saja hal tersebut menghambat pasokan kebutuhan sehari-hari. Jarak ini akhirnya menyebabkan harga barang kebutuhan sehari-hari dari Putusibau lebih mahal dibanding Lubok Antu. Hampir 80\% kebutuhan makan dan minuman masyarakat di pasok dari Negara tentangga yakni Lubuk Antu Negara Malaysia, dikarenakan jarak tempuhnya yang sangat dekat dibandingkan jarak ke Ibu kota Kabupaten Kapuas Hulu. Berdasarkan informasi warga setempat, pasokan sandang pangan seperti beras, gula, minyak goreng, susu dan segala jenis sayur mayor serta lauk pauknya didatangkan dari Lubok Antu (Malaysia). Hanya segelintir saja yang dominan berasal dari produk Indonesia seperti obat-obatan, pakaiaan dan rokok.

Potensi yang ada di Nanga Badau, baik itu potensi flora dan fauna, potensi sosial budaya, potensi ekonomi dan potensi pariwisata, belum banyak dieksplorasi dengan baik sehingga belum mampu memberikan sumbangan yang signifikan terhadap proses pembangunan. Usaha-usaha ekplorasi yang ada pun cenderung bersifat individu dan berpotensi pada eksploitasi yang menguntungkan pihak-pihak tertentu saja. Pertambangan Emas Tanpa Izin (PETI) misalnya, dilakukan oleh sebagian masyarakat yang memberikan keuntungan pada pelaku usaha saja yang bahkan merugikan kepentingan umum seperti pencemaran lingkungan. Poteni wisata Danau Sentarum juga belum memberikan sumbangan banyak terhadap income (pendapatan) masyarakat setempat dengan indikasi bahwa turis yang berkunjung masih sangat kecil jumlahnya. Potensi sumber energi minyak yang terkandung di Badau juga belum tersentuh sama sekali sehingga masalah kekurangan energi menjadi masalah utama di Badau. Energi listrik didatangkan dari negara tetangga dan energi Bahan Bakar Minyak (BBM) juga masih sangat terbatas sehingga sebagian dari masyarakat masih membeli BBM dari negara tetangga juga. 


\section{Dayak Iban Lintas Negara dalam Pergulatan Tradisi Daerah Perbatasan}

Sebagai penduduk kawasan perbatasan dari wilayah negara yang terletak pada sisi dalam sepanjang batas wilayah Indonesia dengan negara lain, Iban merupakan salah satu dari sekian kelompok etnis yang ada di pedalaman kawasan perbatasan sekitar Nanga Badau dan Lubok Antu Malaysia, sehingga tempat ini menjadi jalur lintas manusia beda negara. Etnis Iban sebagian menjadi warga negara Malaysia dan sebagaian yang lain Warga Negara Indonesia (WNI). Ruang interaksi seperti pekerjaan, perdagangan dan kekeluargaan yang berlangsung dalam masyarakat Iban di kedua negara membawa pada dinamika kehidupan berbagai aspek masyarakat perbatasan sehingga perubahan sosial terjadi dalam komunitas Iban. Alexander Horstmann $^{8}$ menyebutkan bahwa perbatasan adalah merupakan laboratorium perubahan sosial dan kebudayaan yang penting sehingga menjadi titik strategis dalam studi perubahan sosial.

Prinsip hidup suku Iban di daerah perbatasan seperti ramah dan menghormati pendatang merupakan salah satu bentuk nyata bahwa mereka sangat terbuka dengan adanya arus global dan lokal serta apa yang disebut oleh Prasojo sebagai "glokalisasi."9 Mereka juga memiliki kesadaran diri akan posisi mereka sebagai bagian dari penduduk dunia. Adanya ruang interaksi bagi dunia luar, seperti mudahnya akses keluar masuk ke negara lain mengakibatkan pola interaksi, informasi dan komunikasi etnis Iban menjadi berkembang. Hal tersebut dapat dilihat pada aktivitas masyarakat Iban sehari-hari yang telah memanfaatkan dan menggunakan perangkat handphone, televisi dan teknologi modern lainnya.

Masyarakat Iban dan suku lainnya di Badau tergolong lebih beruntung dibandingkan dengan masyarakat di Senaning. Sejak dibukanya kawasan Badau pada tahun 1990-an, jalur darat Putusibau lintas utara perbatasan

8 Alexander Horstmann, "Incorporation and Resistance: Border-Crosings and Social Transformation in Southeast Asia", Antropologi Indonesia, No. 67. Vol. XXVI, 2002.

9 Lihat Zaenuddin Hudi Prasojo, "Identitas Dayak Katab Kebahan di Kabupaten Melawi Kalimantan Barat: Studi tentang Konstruksi Identitas Etno-Religio pada Masyarakat Dayak", Disertasi, tidak diterbitkan, Yogyakarta: UGM, 2012.Prasojo (2012) yang menjelaskan proses interaksi global dan lokal yang terjadi pada komunitas sub etnis Dayak Katab Kebahan di Kabupaten Melawi yang kemudian dikenal dengan istilah glokalisasi. 
tidak saja menjadi faktor pendorong perubahan sosial ekonomi tetapi juga menjadi alternatif tambahan jalur sungai Embaloh yang sejak zaman nenek moyang telah menjadi jalur satu-satunya untuk menjangkau Badau. Pengerasan serta lapis aspal pada jalan terlihat di sepanjang jalan dari Kecamatan Lanjak menuju Badau yang merupakan upaya pengembangan untuk mempermudah akses masyarakat ke ibu kota kabupaten. Keberuntungan masyarakat Badau juga terlihat dari ketersediaan berbagai fasilitas seperti pusat perputaran jasa dan perdagangan. Sarana jual beli barang dalam bentuk ketersediaan pasar-pasar yang menjual beranekaragam sayur mayur, pakaiaan, bengkel, kios-kios handphone serta penginapan yang juga tersedia bagi warga pendatang. Hal tersebut cukup memberikan kontribusi besar bagi perputaran arus barang dan jasa disetiap warga desa se-Kecamatan Badau.

Hadirnya pusat usaha koperasi usaha simpan pinjam seperti Credit Union (CU) Keling Kumang serta Bank Swasta BPD di kecamatan tersebut membuat masyarakat dari desa-desa Iban bisa menyisihkan hasil kerja berladang maupun menyadap karet untuk ditabung dan dipergunakan untuk keperluan anaknya sekolah maupun keperluan mendadak lainnya. Selain itu, dari penuturan warga Iban, biasanya bagi mereka yang merantau ke Malaysia, umumnya memiliki dua kartu identitas, yakni Kartu Tanda Penduduk (KTP) untuk Negara Indonesia dan ID Card untuk warga Malaysia. Mereka di sana merantau untuk bekerja sebagai buruh tani, kemudian kembali ke Indonesia biasanya dua tahun sekali yakni pada saat Gawai Dayak Iban dan pada saat Natal. Hasil dari kerja Malaysia yakni berupa Ringgit Malaysia dapat membantu mereka untuk kebutuhan modal dan kebutuhan lainnya seperti tabungan di CU dan BPD. Alternatif pekerjaan tersebut dipilih karena dianggap/dirasakan lebih baik daripada pekerjaan yang tersedia di Badau.

Selain itu, adalah hal yang menarik ketika ternyata ditemukan fakta bahwa etnis Iban telah memiliki keadaran yang cukup baik sebagai bagian dari penduduk dunia. Kesadaran ini dibuktikan dengan berubahnya sudut pandang tentang pentingnya akan pendidikan. Hal ini dapat dilihat beberapa anak dari masyarakat Iban yang sudah menyandang gelar sarjana dan ada juga yang masih mengenyam pendidikan di berbagai perguruan tinggi di Kalimantan Barat. Umumnya pekerjaan orang tua dari anak yang sudah 
sarjana tersebut adalah petani kebun yang mengandalkan karet dan CU sebagai sumber utama biaya sekolah dan kuliah.

Namun, kondisi pada umumnya adalah bahwa dari presentasinya, mayoritas penduduk dari desa-desa Iban ini tidak tamat Sekolah Dasar. Dari data kecamatan Badau sebanyak 1558 tidak tamat sekolah, kemudian sebanyak 1640 beberapa orang lulusan SD, sedikit saja yang lulusan SLTP dan SMU. Mereka yang lulusan SLTP dan SMU adalah perangkat Desa. Hal semacam ini bisa dimaklumi karena tingkat minat sekolah dinilai meningkat pada tahun 2000-an sejak dibukanya lintas utara pada tahun 1990. Sekarang sudah banyak anak-anak dari desa Iban ini yang sudah duduk di bangku SLTP dan SLTA. Dapat disimpulkan juga bahwa sudah ada kesadaran untuk menunutut ilmu lebih tinggi, serta ada kebangkitan akan pentingnya pendidikan formal bagi masyarakat Iban untuk mengikuti arus globalisasi saat ini, walaupun belum dibarengi oleh perhatian pemerintah secara lebih serius.

\section{Kesimpulan}

Letak wilayah Badau yang sangat jauh dari Pontianak sebagai ibukota Provinsi Kalimantan Barat, dan secara geografis lebih dekat dengan Negara tetangga Malaysia, tidak membuat surut rasa nasionalisme masyarakat penduduk lokal, warga Dayak Iban dan Melayu Dayau, sebagai bagian dari NKRI. Warga Dayak Iban, misalnya, selama bertahun-tahun tetap berdiri kokoh memegang teguh adat istiadat dan budaya serta NKRI dengan semboyan yang dapat ditemui pada masyarakat Badau yaitu "Garuda di Dadaku, Malaysia di Perutku". ${ }^{10}$ Semboyan tersebut bermakna sangat dalam dan berhubungan erat dengan berbagai aspek kehidupan masyarakat Badau sebagai bagian yang tidak terpisahkan dari mayarakat Indonesia. Makna semboyan warga Dayak Iban tersebut sebenarnya adalah bahwa mereka tetap mengakui bahwa mereka adalah WNI yang patuh, warga yang paham akan kesadaran berbangsa satu bahasa Indonesia, akan tetapi mereka juga tidak bisa menampik bahwasanya isi perut mereka adalah produk negara tetangga.

\footnotetext{
10 Semboyan "Garuda di Dadaku, Malaysia di Perutku” diungkapkan langsung oleh beberapa tokoh masyarakat dan masyarakat kelas bawah yang ditemui peneliti selama di lapangan. Penulis menyampaikan terimakasih dan kredit poin pada Agu Pujianto yang telah mendokumentasikan proses wawancara sehingga poin penting semboyan masyarakat Iban di Badau tersebut dapat terungkap.
} 
Hal ini dikarenakan hampir $80 \%$ warga Iban perbatasan Nanga Badau dengan Lubok Antu memperoleh kebutuhan hidup sehari-hari yang berasal dari produk pangan negara tetangga.

Semboyan masyarakat etnis Dayak Iban bermakna sangat dalam dan strategis. Namun sangat disayangkan kesetiaan mayarakat Badau tersebut belum diimbangi oleh perhatian yang setimpal, khususnya oleh pemerintahan NKRI. Dalam buku ini setidaknya ada tiga poin penting yang dibahas menyangkut kondisi Badau yang sangat memprihatinkan layaknya ungkapan "Badauku Sayang Badauku Malang. Pertama, persoalan kelambanan proses pembangunan adalah salah satu persoalan pokok yang menjadi pendorong munculnya fakta-fakta rendahnya kualitas sarana dan prasarana di Badau. Masalah kualiatas jalan dan jarak yang jauh antara Badau ke Putusibau dan daerah lain di Kabupaten Kapuas Hulu menjadi faktor penting bagi proses pembangunan. Dari Badau, waktu tempuh menuju ibukota kabupaten adalah sekitar 5 jam, sedangkan untuk menyebrang ke kumpung negara tetangga hanya perlu jarak tempuh 15 menit dengan kondisi jalan yang mulus. Selain harga yang lebih murah, akses dan jarak tempuhnya juga mudah mendorong warga Badau untuk berbelanja ke Lubok Antu.

Sebagai gambaran, gula asal Malaysia di Badau Rp. 6.000,- per kilogram, sementara dari Putusibau Rp. 8.000,- Gas Malaysia 15 kg dijual Rp. 150.000,sedangkan Gas Pertamina di Ibu Kota Rp. 165.000,-. Tidak hanya itu, di pinggiran jalan Kecamatan Badau banyak dijumpai Plat kendaraan bernomor polisi asing, yakni mobil dan motor asal Malaysia. Walaupun kendaraan tersebut hanya beroperasi di sekitar Badau dan sekitarnya, serta tidak mempunyai surat menyurat yang lengkap tetapi warga perbatasan mampu membeli mobil tersebut, hal ini dikarenakan mobil dan motor yang dijual di Malaysia harganya berbanding jauh dari Indonesia. Dengan membawa uang dua juta, masyarakat di Badau sudah bisa membawa sepeda motor, dengan uang Rp. 25 juta bisa membawa mobil sekelas Pajero dan Daihatsu. Padahal harga kisaran di Indonesia sekitar ratusan juta rupiah.

Kedua, ketergantungan masyarakat Badau dengan negara lain (Malaysia) di perbatasan tersebut sebenarnya adalah karena persoalan disfungsi negara dalam berbagai aspek pembangunan. Disfungsi negara tampak pada masalah energi yang menjadi unsur utama dalam pembangunan; listrik 
dipasok dari Lubok Antu karena NKRI tidak mampu menyediakan kebutuhan listrik masyarakat. Disfungsi negara juga tampak dari berbagai aspek seperti rendahnya dukungan pemerintah kepada kinerja lembaga-lembaga negara sehingga keterpaduan kebijakan tidak berjalan dengan baik. Untungnya, meskipun lebih banyak ketergantungan pada negera tetangga dalam berbagai penopang sendi kehidupan, masyarakat Iban di Badau tetap setia dengan mengatakan "apapun yang terjadi, kami tetap cinta Indonesia, darah dan jiwa kami untuk Republik Indonesia."11

Faktor kekayaan SDA menjadi salah satu penghibur masyarakat Iban dan etnis lainnya di Badau sehingga mereka masih memiliki nasionalisme yang tinggi. Ritme kehidupan berjalan dengan lancar penuh kebersamaan dan kesederhanaan dengan dukungan lauk pauk hasil limpahan hasil bumi. Masyarakat masyarakat Badau tidak susah payah mengenai air bersih karena air terjun Wong Kijang di Dusun Sungai Telian menyediakan limpahan air bersih yang dibutuhkan walaupun mereka harus mendapatkannya secara tradisional karena pemerintah Indonesia belum secanggih pemerintah Malaysia yang mampu menyediakan air bersih dengan system yang lebih baik.

Ketiga, persoalan kelambanan pembangunan dan isu tentang disfungsi negara di Badau ternyata berimplikasi pada persoalan identitas keindonesiaan bagi banyak orang. Secara kultural memang masyarakat Badau, khususnya etnis Iban hidup berdampingan dengan kemajemukan, baik itu agama, budaya dan suku warga yang lain. Namun karena persoalanpersoalan keseharian yang berkaitan dengan kebutuhan hidup maka masyarakat Badau termasuk etnis Dayak Iban harus berhadapan dengan pilihan-pilihan sulit: mempertahankan menjadi warga NKRI dengan kondisi kehidupan yang kurang beruntung dan merantau ke Malaysia mengikuti sanak keluarganya yang tinggal di negeri jiran tersebut dengan harapan nyata atas kehidupan yang lebih baik.12 Sebagain kecil etnis Dayak Iban ada yang memutuskan untuk menyebarang dan menetap di Malaysia, namun sebagian

\footnotetext{
${ }^{11}$ Kutipan hasil wawancara dengan Tumenggung Lutther di Nanga Badau pada Januari 2013.

12 Walaupun mempunyai nenek moyang yang sama, akan tetapi kesejahteraan antara Iban Indonesia dan Malaysia kondisi sosial ekonomi dan pendidikan sangat berbanding jauh.
} 
besar yang lain ternyata masih memiliki nasionalisme yang tinggi pada NKRI. Mereka memanfaatkan kemudahan-kemudahan yang diberikan oleh negeri jiran, namun mereka tetap setia pada NKRI. Lalu, sampai kapan mereka akan tetap setia jika kondisinya tidak berubah atau malah semakin buruk? ${ }^{13}[\mathrm{w}]$

13 Berbanding jauh dengan Iban yang ada di Indonesia, mereka terlihat masih sangat kekurangan, walaupun mereka mereasa cukup untuk kebutuhan pangan, akan tetapi kesejahteraan mereka masih kurang diperhatikan, sentuhan PNPM misalnya, itu hanya sebatas perbaikan jalan setapak sepanjang ratusan meter. Akan tetapi, walaupun nasib mereka berbanding terbalik dengan kerabatnya di rumpun tetangga, akan tetapi jiwa dan raga mereka tetap memegang teguh Negara Kesatuan Republik Indonesia, menjadi sebuah kesatuan yang utuh, menjadi sebuha komunitas adat yang memegang teguh adat dan kearifan lokal asli pedalaman Kalimantan sehingga dayak mempunyai nama terjemahan menjadi "DAYAK" (Daerah Adat Yang Asli Kalimantan). 


\section{BIBLIOGRAFI}

Fariastuti, "Mobility of People and Goods Across the Border of West KalimantanSerawak", Antropologi Indonesia, No. 67,Vol. XXVI, 2002.

Horstmann, Alexander "Incorporation and Resistance: Border-Crosings and Social Transformation in Southeast Asia", Antropologi Indonesia, No. 67. Vol. XXVI, 2002.

Marsetio, "Konstruksi Marginalitas Masyarakat Perbatasan, Studi Kasus Kepulauan Natuna", Disertasi, tidak diterbitkan, Yogyakarta: UGM, 2012.

Hudi Prasojo, Zaenuddin, "Identitas Dayak Katab Kebahan di Kabupaten Melawi Kalimantan Barat: Studi tentang Konstruksi Identitas Etno-Religio pada Masyarakat Dayak", Disertasi, tidak diterbitkan, Yogyakarta: UGM, 2012.

Siburian, Robert, "Entikong: Daerah Tanpa Krisis Ekonomi di Perbatasan Kalimantan Barat-Serawak", Antropologi Indonesia, No. 67, Vol. XXVI, 2002.

Tirtosudarmo, Riwanto, "Tentang Perbatasan dan Studi Perbatasan: Sebuah Pengantar", Antropologi Indonesia, No. 67, Vol. XXVI, 2002.

"Kalimantan Barat sebagai "Daerah Perbatasan": Sebuah Tinjauan Demografi Politik," Antropologi Indonesia, No. 67, Vol. XXVI, 2002.

Wadley, Reed L., "Border Studies Beyond Indonesia: A Comparative Perspective", Antropologi Indonesia, No. 67, Vol. XXVI, 2002. 
